DOI:

Світлана Булавенко, кандидат педагогічних наук, докторант Інституту проблем виховання НАПН України

\title{
РОЛЬ ВОЛОНТЕРСЬКОЇ ДІЯЛЬНОСТІ В ФОРМУВАННІ СОЩАЛЬНОЇ АКТИВНОСТІ УЧНІВ У ЗАКЛАДАХ ЗАГАЛЬНОЇ СЕРЕДНЬОЇ ОСВІТИ
}

У статті аналізується та узагальнюється роль волонтерської діяльності в формуванні соціальноі активності підлітків в закладах загальної середньої освіти, описуються три групи соціально значущих мотивів, щио спонукають підлітків до волонтерської діяльності. Проаналізовано актуальність волонтерськоі діяльності для формування особистості у підлітковий період. Узагальнено результати проведеного дослідження щзодо готовності підлітків до волонтерської діяльності. Окреслено основні напрямки і види волонтерської діяльності. Наводяться приклади волонтерської діяльності підлітків у закладі загальної середньої освіти.

Ключові слова: волонтерська діяльність; соціальна активність підлітків; напрямки $і$ види волонтерської діяльності у закладі загальної середньої освіти; мотивація.

Jim. 6.

Svitlana Bulavenko, Ph.D.(Pedagogy), Doctoral Student of the Institute of Education Problems of the National Academy of Sciences of Ukraine

\section{THE ROLE OF VOLUNTARY ACTIVITY IN FORMING THE SOCIALACTIVITY OF STUDENTS IN GENERAL BASIC EDUCATION INSTITUTIONS}

The article analyzes and generalizes the role of volunteers in shaping the social activity of adolescents in general secondary education institutions, describes three groups of socially important motivations that motivate adolescents to volunteer work. The actuality of volunteer activity for the formation of the personality during the teenage period is analyzed. The results of the conducted research on the readiness of adolescents to volunteer activity are summarized. The author outlines the main directions and types of volunteer activities. Examples of volunteering activities of adolescents in an institution of general secondary education are given.

In order to analyze the content of the volunteer activity, the conditions and mechanisms for its use in the practice of extra-curricular work in the institution of general secondary education, a special study was conducted with the help of the developed "Questionnaire of a potential volunteer". In the course of the survey, it was discovered that adolescents are positively involved into volunteering, are willing to engage in volunteering, but were not informed enough about volunteer activity. The main areas of activity of volunteers in the institution of general secondary education are: promotion of a healthy lifestyle, advocacy of legal knowledge, assistance to ATO soldiers, assistance to socially vulnerable people, needy layers of the population, an organization of creative activity, patronage work with children, moral education of the individual.

The types of volunteers used were as follows: assistance to such social categories of citizens as: the elderly, people with disabilities, migrants, refugees and others; educational work aimed at the prevention of tobaccosmoking, drug addiction, adolescent crime; charity concerts and theatrical performances in orphanages; ecological marches, garbage collection and pollution; promotion of a healthy lifestyle, etc.

As a result of the study, it was found that volunteer activity of students contributes to increasing social activity and active participation in volunteering contributes to the development of such social skills as. communicative abilities; experience of responsible interaction; leadership skills; self-organization; executive discipline; protection and advocacy of rights and interests; experience with the group; organizational skills; initiative and others.

Keywords: volunteer activity; social activity of adolescents; directions and types of volunteer activity in the institution of general secondary education; motivation.

П остановка проблеми. Сучасне динамічне суспільство потребує соціально розвинених людей, які здатні самостійно приймати рішення, відчувати себе впевнено в соціумі.

Для того щоб відчути здатність активно впливати на ситуацію, людина повинна постійно взаємодіяти зі світом, формуючи свою життєву позицію, свої життєві сенси [3], оскільки саме у взаємодії вона починає відчувати себе частиною реального світу, оцінювати свої сили й активізувати свій соціальний потенціал.

Потреба в соціальній активності - одна 3 найгостріших проблем підліткового віку. Як вважає І.Д. Бех, коли дитина занурюється в потік колективного життя, тоді виявляються такі сторони дитячої індивідуальності, які при всіляких інших умовах не можуть проявитися або бути 


\section{РОЛЬ ВОЛОНТЕРСЬКОЇ ДІЯЛЬНОСТІ В ФОРМУВАННІ СОЦІАЛЬНОЇ АКТИВНОСТІ УЧНІВ У ЗАКЛАДАХЗАГАЛЬНОЇ СЕРЕДНЬОЇОСВІТИ}

виявлені. У колективі дитина не розчиняється, а, навпаки, знаходить умови для виявлення та розквіту своїх кращих сторін [1].

На кожному віковому етапі активність має тенденцію до зростання, відповідно до обсягу соціальних обов'язків і того досвіду, що набувають учні. У цих умовах соціальна активність стає найважливішою передумовою у формуванні соціального потенціалу особистості, ії успішної адаптації до суспільного життя з урахуванням тенденцій прогресу суспільства. Будь-яка діяльність може бути активною тільки в тому випадку, якщо вона $є$ наслідком внутрішніх спонукань і потреб особистості в реалізації свого соціального потенціалу [6].

Сьогодні кардинальні перетворення в суспільстві вимагають створення науково обгрунтованої системи організації позаурочної діяльності у закладах загальної середньої освіти, спрямованої на формування соціально активної особистості учнів. Наше життя на перший план висуває необхідність використання передових, інноваційних засобів і методів навчання й виховання [1].

Аналіз останніх досліджень та публікацій. Волонтерську діяльність як феномен та багаторічний досвід волонтерства подано в роботах багатьох зарубіжних авторів, зокрема Д. Сміта та А. Пауел (США). Тему волонтерства грунтовно розкрили в своїх дослідженнях вітчизняні науковці І. Бех, 3. Бондаренко, Р. Вайнола, Л. Канішевська, А. Капська, О. Караман, Н. Комарова, В. Кратінова, Н. Ларіонова, О. Песоцька, С. Харченко, Н. Янц та інші активно досліджують соціально-педагогічні аспекти волонтерської діяльності. Проте, не достатньо уваги приділено саме ролі волонтерської діяльності у формування соціальної активності підлітків.

Метою статті $\epsilon$ аналіз та узагальнення ролі волонтерської діяльності в закладах загальної середньої освіти в формуванні соціальної активності підлітків.

Виклад основного матеріалу. На сучасному етапі розвитку соціальних відносин однією 3 найважливіших проблем $є$ розвиток соціальної активності підлітків. Адже підлітковий період це період становлення особистості та переходу 3 дитинства в доросле життя.

Крім того, наступний етап в житті старшого підлітка - період юності, на протязі якого ставляться важливі життєві завдання, як наприклад, професійне самовизначення. Тому, щоб підлітку було легше зійти на вищий етап - етап дорослості, йому потрібно володіти певними якостями, такими як самоконтроль, відповідальність, вміння налагоджувати контакт, які допоможуть йому в подальшій самореалізації [5].

Формувати особистість підлітка, “соціалізувати”, вводити його в “світ дорослості" повинні безпосередні вихователі - батьки і вчителі. Якщо цього не робити, то підліток знайде способи проникнути в цей світ і без допомоги дорослих. Небажання чи невміння дорослих зрозуміти нові устремління підлітка ще більше збільшують потребу в спілкуванні з однолітками, оскільки тут, в середовищі однолітків він знаходить визнання і підтримку. Спілкування 3 товаришами $є$ особливою шкалою розвитку соціальних якостей школяра, і сила впливу однолітків прямо пропорційна ступеню незадоволеності підлітка спілкуванням з дорослими [3].

Особистість, не володіючи соціальною активністю, “розчиняється" в соціумі. Цьому сприяє й сучасна система виховання, орієнтована на підготовку людини до виконання вузьких соціальних ролей. На сьогоднішній день виникла необхідність не тільки навчити підростаюче покоління успішно пристосовуватися до конкретних умов і вимог суспільства, а й розвивати соціально активну й самостійну особистість.

3 огляду на соціальні чинники та зовнішне середовище (в тому числі позакласну діяльність), а також спираючись на природні передумови особистості, сучасна система виховання покликана розвинути в дитини потребу й здатність до самовдосконалення [3].

У сучасній теорії та практиці існує протиріччя між необхідністю виховувати соціальну активність і відсутністю достатньої кількості методичних рекомендацій, як це робити.

У своій практичній діяльності з формування соціальної активності підлітків ми пропонуємо учням спробувати свої сили в різних видах діяльності, а також просимо їх дати власну оцінку свого рівня соціальної активності. Також для розвитку особистості ми використовували наступні прийоми, які допомагали розкрити потенціал учнів, a саме:

- завдання на “включення" самореалізації (творчість в змісті роботи - написати есе про свої захоплення, зробити ескіз сторінки шкільної газети, відібрати потрібний матеріал для розробки сценарію);

- завдання, орієнтовані на спільний розвиток школярів (спільна творчість із застосуванням спеціальних технологій і форм групової роботи створення групових проектів 3 навчальної дисципліни, написати сценарій для шкільного 


\section{РОЛЬ ВОЛОНТЕРСЬКОЇ ДІЯЛЬНОСТІ В ФОРМУВАННІ СОЦАЛЬНОЇ АКТИВНОСТІ УЧНІВ}

У ЗАКЛАДАХЗАГАЛЬНОӤ СЕРЕДНЬОЇ ОСВІТИ

фільму чи відеоролика, участь в репетиціях тощо);

- завдання й група прийомів організації освітньої діяльності, спрямованої на розвиток прагнення змінити себе, вдосконалюватися й саморозвиватися (це дозволило простежувати прояв різних якостей: індивідуальність, терпіння, ініціативність, творчість, практичність, відповідальність, готовність і вміння взаємодіяти тощо). Завдання вчителів і батьків при цьому полягає в тому, щоб звертати увагу на дрібні особливості особистості школяра та з повагою поставитися до ії̈ проявів, навіть коли ці прояви не відповідають їхнім очікуванням. Слід підкреслити, що важливим є переконати підлітка в цінності, корисності й необхідності проявів його індивідуальності [5].

Велике значення для формування соціальної активності підлітка має формування таких особливостей особистості учнів, як почуття обов'язку, соціальної відповідальності, звички до систематичної праці, наявність широких пізнавальних інтересів, а в кінцевому рахунку розуміння тієї ролі, яку відіграє школа для їх майбутнього життя. Ось чому дуже важливо, щоб в підлітковому віці перед школярами вже виникла проблема самовизначення [5], тобто уявлення про своє майбутнє місце в житті, стійкий інтерес до будь-якої професії або до певного виду діяльності.

Саме ті учні, у яких такого роду стійкі інтереси сформувалися, досить чітко уявляють собі, до чого вони будуть прагнути по закінченню школи. Вони, як правило, відрізняються організованістю поведінки, постійною спрямованістю на досягнення поставлених цілей. Образ майбутнього може виступати як характеристика становлення соціального потенціалу особистості, оскільки одним із показників успішної соціалізації підлітка є сформованість його життєвих планів. Саме цей показник важливий для підлітка, який готується до зміни соціального статусу, що вибирає свій професійний шлях і ціннісні орієнтири, які пов'язані з його уявленнями про майбутнє [6]. Для того, щоб сформувати саме таку особистість, навчальний заклад має докласти зусилля для розвитку таких якостей як соціальна зорієнтованість та соціальна свідомість. Процес виховання на сьогодні передбачає підготовку такого покоління, яке здатне адаптуватися до будь-якої ситуації, навчатися, проявляти активність і талант на благо не тільки самого себе, а й суспільства в цілому.

Участь у волонтерському русі допомагає підростаючому поколінню в професійному самовизначенні, так як це прямий шлях до самостійного життя, тут завжди $є$ можливість проявити себе, спробувати в різних сферах діяльності й визначитися 3 вибором життєвого шляху, реалізуючи свої ідеї у вирішенні соціальних проблем. Волонтерство для школяра - це можливість отримати початковий професійний досвід, досвід спілкування, взаємодії, партнерства [3].

У своєму дослідженні, присвяченому аналізу впливу добровольчої діяльності на формування соціальної активності ми виділили три групи провідних соціально значущих мотивів. Перша група мотивів - це самореалізація особистісного потенціалу, можливість проявити свої здібності та можливості в соціально значущій громадській діяльності. Наступна важлива група - це суспільне визнання, почуття соціальної значущості, можливість утвердитися в власних очах, відчути причетність до суспільно корисної справи. Ще одну групу мотивів ми визначаємо як можливість самовираження та самовизначення.

Волонтерська робота дозволяє дитині: висловити своє внутрішнє " $Я$ " і утвердитися в життєвих цінностях; мати можливість спілкування та дружньої взаємодії з однодумцями; отримати досвід відповідального лідерства та соціальної взаємодії; набути навички, необхідних у подальшому житті, як для виконання ролі лідера так і виконавської діяльності; висловити громадянську позицію активною діяльністю, спрямованою на захист власних поглядів і цінностей [4].

Таким чином, в процесі підготовки та реалізації добровольчої діяльності учні набувають впевненості в своїх здібностях і вибудовують нові соціальні зв'язки, навчаються новим навичкам, отримують можливість знайти себе і закласти в своє життя ті цінності й звички, які дозволять людині вести здорове, продуктивне, насичене життя, стати повноцінним членом суспільства [2].

У результаті конвергенції реальної поведінки й взаємодії особистості зі зовнішнім світом відбувається моральний (готовність до служіння, співчуття, толерантність), соціальний (формування соціальної відповідальності, навички ефективної взаємодії в суспільстві), психічний (розвиток різних психічних функцій) і діяльнісний (соціальна активність, діяльнісна спроможність) розвиток особистості, що є основою саморозвитку та самовдосконалення [6].

3 метою аналізу змісту волонтерської діяльності, умов і механізмів іiі застосування в практиці позаурочної роботи у закладі загальної середньої освіти було проведено спеціальне 


\section{РОЛЬ ВОЛОНТЕРСЬКОЇ ДІЯЛЬНОСТІ В ФОРМУВАННІ СОЦІАЛЬНОЇ АКТИВНОСТІ УЧНІВ УЗАКЛАДАХЗАГАЛЬНОӤ СЕРЕДНЬОЇ ОСВІТИ}

дослідження. Нами була розроблена “Анкета потенційного волонтера”. Завданнями анкетування були: виявлення ставлення підлітків до участі в волонтерській діяльності; вивчення мотивів і схильностей, через які учні готові займатися волонтерською діяльністю; 3'ясування ступеня інформованості про волонтерську діяльність.

В ході дослідження було опитано 414 учнів 5 9 класів Ніжинської гімназії № 3 Ніжинської міської ради Чернігівської області. Аналіз результатів анкетування дозволив нам виявити деякі особливості з досліджуваної проблеми. Одне 3 питань "Анкети потенційного волонтера" було сформульоване наступним чином: "Чи знаєте Ви, що таке волонтерська діяльність?”.

Більше 80\% (253 підлітків) опитаних вказали, що волонтерська діяльність є добровільною допомогою будь-кому. Близько 20\% (61 учень) відповіли, що це - добровільна безоплатна допомога нужденним. Тут слід уточнити, що безоплатність, тобто відсутність розрахунку на винагороду, $є$ значущою ознакою волонтерства.

На наступне питання "Чи хочете ви стати волонтером?” були дані наступні варіанти відповідей: 1 . Так, я хочу стати волонтером $-21 \%$. 2. Хочу стати потенційним волонтером $-22 \%$. 3. Сумніваюся, так як я погано собі уявляю, що це таке $-38 \%$. 4. Нi, не хочу - $19 \%$. У цьому запитанні можна було вибирати тільки один варіант відповіді. Нас трохи здивувало, що 59 підлітків не захотіли брати участь в добровольчої діяльності. 3 нашї точки зору, вони все ще не усвідомлюють важливості волонтерської діяльності й не бачать необхідності участі в ній.

На питання "Яким видам діяльності Ви віддаєте перевагу?” 60 \% учнів обрали колективну діяльність (в групі з іншими людьмиоднодумцями); 31 \% - вибрали, пов'язану безпосередньо 3 людьми (в тому числі 3 незнайомими); діяльність пов'язану зі спілкуванням не вибрав ні один учень. Досить високий рейтинг за показником “індивідуальна діяльність (робити що-небудь самому індивідуально)" - 31 \%. Така досить велика, на перший погляд, кількість учнів, бажаючих займатися будь-якою діяльністю індивідуально ми пов'язуємо, з сучасними соціально-економічними умовами, які свідчать про те, що сучасна молодь в першу чергу розраховує перш за все на себе. Тут слід уточнити, що можна було вибирати декілька відповідних варіантів відповіді.

Четверте запитання стосувалося того, що привертає увагу підлітків у волонтерській діяльності. Були отримані наступні результати: $63 \%$ - можливість допомогти іншим; $22 \%-$ отримання нового досвіду; 17 \% - нові інтереси; $15 \%$ - зустрічі з новими людьми. У цьому питанні також можна було вибрати дві відповіді. Якісна характеристика отриманих відповідей черговий раз підтверджує нашу думку, що волонтерську діяльність можна розглядати як важливу умову і ефективне засіб підвищення соціальної активності учнівської молоді та виконання завдань професійної соціалізації студентів.

На запитання "Кому б Ви хотіли надавати допомогу в першу чергу” відповіді розподілились наступним чином: $36 \%$ - дітям-сиротам; $24 \%$ хворим дітям; 12 \% - інвалідам; $17 \%$ - літнім людям. Свій варіант запропонували $22 \%$ учнів. У числі тих, кому вони запропонували б допомогу були діти в дитячих садочках, воїни АТО. Ми припускали, що на першому місці виявиться пункт “хворим дітям", але вибір “дітям сиротам" виявився більшим. Подальша співбесіда показала, що багато підлітків керувалися принципом “у хворих дітей хоч батьки $\epsilon$ ”, які в певній мірі вирішать проблеми своїх дітей.

Нас також цікавило в дослідженні і те, яким чином учні готові надавати волонтерську допомогу. Шляхом участі в організаційній роботі (підготовка і проведення заходів, свят) відзначили $70 \%$ опитаних; $26 \%$ - готові віддавати свої речі, книги; $17 \%$ - хочуть надавати допомогу своєю працею; і 7\% - відповіли - “всім, чим зможемо”. Позиція "Ваші варіанти" не відрізнялася різноманітністю й оригінальністю, що зайвий раз говорить про те, що уявлення учнів про волонтерську діяльність $є$ неповними, тобто зміст добровольчої діяльності вони бачать в досить обмеженому форматі.

У результаті проведеного дослідження ми з'ясували, що учні мають бажання брати участь у волонтерській діяльності, проте дуже мало знають про неї. Тому, за нашою пропозицією, у 2014 року створено в Ніжинській гімназії № 3 об'єднання волонтерів “Від щирого серця”, як один із напрямків роботи учнівського менеджменту.

Основними напрямками діяльності волонтерів $€$ : пропаганда здорового способу життя; пропаганда правових знань; допомога воїнам АТО; допомогу соціально вразливим людям, нужденними верствам населення тощо; організація творчої діяльності; шефська робота 3 малюками; моральне виховання особистості тощо.

Використовувані види діяльності волонтерів були такі: допомога таким соціальним категоріям громадян, як: особи похилого віку, люди 3 обмеженими можливостями, мігранти, біженці та 

У ЗАКЛАДАХЗАГАЛЬНОЇ СЕРЕДНЬОЇ ОСВІТИ

інші; просвітницька робота, спрямована на профілактику тютюнопаління, наркоманії, підліткової злочинності; благодійні концерти і театральні виступи в дитячому будинку; екологічні марші, прибирання сміття та забруднень; пропаганда здорового способу життя тощо.

Спершу ми постійно спонукали учнів до ініціативності, самостійності та волонтерської діяльності. Проте пізніше учні вже самі стали ініціаторами багатьох справ, стали більш самостійними.

Так учні розробили заповіді волонтера:

1. Будь вірний загальній Справі.

2. Цінуй важливість своєї ролі. Немає маленьких ролей - $є$ спільна справа.

3. Розумій завдання, яке ти виконуєш.

4. Зіставляй свої інтереси з потребами оточуючих і з завданням, яке виконуєш.

5. Працюйщирой поділися зіншими новими ідеями про те, як зробити роботу ще більш ефективною.

6. Дорожи командним духом, прагни до вирішення конфліктних ситуацій без залучення в них керівництва.

7. Відкрий себе можливостям розвитку емпатії, впевненості в собі й відповідальності.

8. Розвивай свою самооцінку й готовність до співпраці.

9. Гордися кар'єрою волонтера. Вона значно збільшує багатство душі.

Волонтери гімназії стали частими гостями дошкільних установ, в яких проводять майстеркласи та театралізовані вистави 3 правил дорожнього руху, поведінки в громадських місцях, вивчення людських чеснот, екскурсії в музеї міста тощо. Щорічно в Ніжинській гімназії № 3 зусиллями волонтерів проводиться фестиваль пам'яті Олега Бикова, який загинув під час бойових дій на Донбасі. Волонтери готують вітальні листівки та сувеніри для воїнів АТО. 3 метою патріотичного виховання волонтери беруть активну участь в акціях, присвячених Дню захисника вітчизни, тижня Небесної сотні, День пам'яті героїв Крут, Дню Соборності України, 9 травня тощо. С активними учасниками гурту “Джура" й допомагають в організації змагань між загонами “Джури”.

Волонтери також небайдужі до проблем екології. Вони щорічно в квітні організують участь дітей в екологічному марафоні $з$ прибирання узбережжя річки Остра. Розуміючи значимість пропагандистської роботи, волонтери гімназії виходять на вулиці міста, привертаючи увагу до проблем паління. Також вони спільно 3 співробітниками ДАЇ закликають протидіяти порушенню правил дорожнього руху. Волонтери не тільки самі пропонують допомогу, а й відгукуються на пропозиції.

Варто зазначити, що кількість підлітків, залучених до волонтерської діяльності, постійно збільшується. На сьогоднішній день їх понад двісті осіб.

Для нас це дуже значимий результат, який виражається не стільки в цифрах, скільки в палаючих ідеями, енергією й добром обличчях дітей, в розумінні, що вони потрібні гімназії, місту, країні, світу. Діти розуміють, що волонтер - це не професія, це не захоплення, це спосіб життя.

Отже, волонтерська діяльність створює сприятливі умови для розвитку особистості підлітка, допомагаючи проявитися індивідуальності, розвинутися, стати соціально активним громадянином. Волонтерський рух - це перспективне, активне майбутнє для випускників шкіл, які обов'язково стануть відмінними співробітниками, цінними кадрами і хорошими батьками.

Висновок. Отже, в результаті проведеного дослідження ми можемо сформулювати висновки про те, що волонтерська діяльність учнів сприяє підвищенню соціальної активності та активна участь в добровольчої діяльності сприяє розвитку таких соціальних навичок, як: комунікативні здібності; досвід відповідальної взаємодії; лідерські навички; самоорганізація; виконавська дисципліна; захист і відстоювання прав та інтересів; досвід роботи з групою; організаторські здібності; ініціативність та інші.

\section{ЛIТЕРАТУРА}

1. Бех І. Д. Виховання особистості : у 2 кн. Кн. 2 : Особистісно орієнтований підхід: науково-практичні засади : навч.-метод. посіб. Київ, 2003. 344 с.

2. Бондаренко 3. П. Організація волонтерської роботи за умов вищого навчального закладу. Волонтерство як ресурс сочіальної роботи у громадi : зб. ст. Київ, 2006. С. 24-33.

3. Вихватенко М. Т., Догадайло Н.І. Зміст і форми неформальної освіти 3 огляду на завдання громадянського виховання. Освіта та пед. наука. 2012. № 4 (153). С. 44- 49 .

4. Історія, теорія та практика волонтерського руху в Україні : навч.-наук.-метод. посіб. для студентів, магістрантів, аспірантів та спеціалістів у галузі соц. роботи, соц. педагогіки / С. Я. Харченко, О. Л. Караман, В.О.Кратінова [та ін.]. Луганськ, 2009. 403 с.

5. Канішевська Л. В. Виховання соціальної зрілості старшокласників загальноосвітніх шкіл-інтернатів у позаурочній діяльності : монографія. Київ, 2011. 368 с.

6. Янц Н. Д. Основи діяльності волонтерів : курс лекцій. Переяслав-Хмельницький, 2009. 200 с.

\section{REFERENCES}

1. Bekh, I. D. (2003). Vykhovannia osobystosti : u 2 kn. 
Kn. 2 : Osobystisno oriientovanyi pidkhid: naukovopraktychni zasady: navch.-metod. posib.[Upbringing of personality: in 2 books. Book. 2: Person-centered approach: scientific and practical background: teaching-method. manual]. Kyiv, 344 p. [in Ukrainian].

2. Bondarenko, Z. P. (2006). Orhanizatsiia volonterskoi roboty za umov vyshchoho navchalnoho zakladu [The organization of volunteer work in higher education]. Volunteering as a Community Social Work Resource: Collection of articles. Kyiv, pp. 24-33. [in Ukrainian].

3. Vykhvatenko, M. T. \& Dohadailo, N.I. (2012). Zmist i formy neformalnoi osvity $\mathrm{z}$ ohliadu na zavdannia hromadianskoho vykhovannia [The content and Forms of Non-Formal Education in Respect of Civic Education Tasks]. Education and ped. science. No. 4 (153), pp. 4449. [in Ukrainian].

4. Istoriia, teoriia ta praktyka volonterskoho rukhu $v$ Ukraini : navch.-nauk.-metod. posib. dlia studentiv, mahistrantiv, aspirantiv ta spetsialistiv u haluzi sots. roboty, sots. pedahohiky [History, theory and practice of volunteer movement in Ukraine: teaching-scientificmethod. manual for students, undergraduates, graduate students and specialists in the field of soc. works, soc. pedagogy]. S. Ya. Kharchenko, O. L. Karaman, V.O.Kratinova et al. Luhansk, 2009. 403 p. [in Ukrainian].

5. Kanishevska, L. V. (2011). Vykhovannia sotsialnoi zrilosti starshoklasnykiv zahalnoosvitnikh shkilinternativ u pozaurochnii diialnosti : monohrafiia [Education of social maturity of high school students of boarding schools in extra-curricular activity: monograph]. Kyiv, 368 p. [in Ukrainian].

6. Yant, N. D. (2009). Osnovy diialnosti volonteriv : kurs lektsii [Basics of volunteer activity: a course of lectures]. Pereiaslav-Khmelnytskyi, 200 p. [in Ukrainian].

Стаття надійшла до редакції 21.06.2019

УДК 378.091

DOI:

Юрій Безрученков, кандидат педагогічних наук, дочент кафедри туризму, готельної і ресторанної справи, Дз “Луганський наџіональний університет імені Тараса Шевченка”

\section{ТВОРЧИЙ ПОТЕНЦАЛ ЯК ЕЛЕМЕНТ КОНКУРЕНТОСПРОМОЖНОСТІ МАЙБУТНЬОГО ФАХІВЦЯ}

Стан справ у сфері послуг вимагає від навчальних закладів формування творчої особистості, яка має прагнення до пошуку неординарних варіантів виходу з ситуацій. Сьогоденна підготовка фахівців для сфери послуг спрямована виключно на підготовку кваліфікованих фахівців, автор статті наголошує про необхідність формування у студентів творчого потенціалу та актуалізує питання підготовки кадрів $в$ навчальних закладах, які б мали достатній творчий потенціал, здатний активізувати творче мислення.

Ключові слова: професійна підготовка студентів; формування творчого потенціалу; підготовка сучасних фахівиів сфери обслуговування; професійна освіта; професійна культура.

Лim. 5.

Yuriy Bezruchenkov, Ph.D.(Pedagogy), Associate Professor of the Tourism, Hotel and Restaurant Affairs Department, Luhansk Taras Shevchenko National University

\section{CREATIVE POTENTIALAS A COMPETITIVE FUNCTIONAL ELEMENT OF THE FUTURE SPECIALIST}

The training of specialists for the service sector is aimed exclusively at the training of qualified professionals, competent, flexible and mobile, with the creative approach to solving the problem prevailing over other means. The current state of affairs in the sphere of hotel and restaurant business and tourism demands from the society as a whole and educational establishments, in particular the formation of a person who has creativity, craving for the search for extraordinary variants of the way out of the situation with the smallest losses, sufficient level of intellectual development, behavioral flexibility, rationalism and autonomy, which is extremely necessary in the actual harsh conditions of doing business in principle. The terms of work in the sphere of hotel and restaurant business and tourism are filled with a huge number of crisis, stressful situations, which require from the employees of lightningfast acceptance of flexible decisions with non-standard formulation. Today it is impossible to surprise an employer and get an ordinary job with the ability to solve trivial, standard tasks. On this basis, the issue of training staff in educational institutions that would have sufficient creative potential, able to intensify creative thinking and quickly find opportunities to solve problems is very acute.

The author of the article notes that in the education system more attention should be paid to the development of creative thinking and creative approach of students especially those who will work in the service sector. The 